\title{
CYCLOOXYGENASE-2 (COX-2) EXPRESSION ON TESTIS CONNECTIVE TISSUE OF Rattus norvegicus AFTER TREATMENT WITH BETEL NUT EXTRACT (Areca catechu)
}

\author{
EKSPRESI CYCLOOXYGENASE-2 (COX-2) PADA JARINGAN TESTIS TIKUS \\ (Rattus norvegicus) AKIBAT PAPARAN EKSTRAK BIJI PINANG (Areca catechu)
}

\author{
Muslim Akmal', Aulanni'am**, dan Wibi Riawan*** \\ * Laboratorium Embriologi, Fakultas Kedokteran Hewan, Universitas Syah Kuala, NAD. \\ ${ }^{* *}$ Fakultas MIPA Universitas Brawijaya Malang \\ *** Laboratorium Biomolekuler Fakultas Kedokteran Universitas Brawijaya Malang
}

\begin{abstract}
Betel nut contains alcaloids such as arecoline, arecaine, arecaidine, arecolidine, guvacine, guvacoline and isoguvasine. Arecoline has ability to change gonad morph-function, including shape abnormality of sperm. This research was conducted to prove the ability of betel nut extract (Areca catechu) in causing apoptosis on testis connective tissue of Rattus novergicus. This research used male; 2-3 months age, 150-200 grams body weight of white rats Rattus norvegicus strain Wistar. The rats were divided into 5 groups in equal number, 3 rats respectively. They were a control group without treatment and 4 groups as treatment groups which were given doses of betel nut extract, i,e., 1, 2, 3 and 4 gram during seven days. The result showed that dose variation of betel nut extract could induction of COX-2 expression on rats (Rattus norvegicus) strain Wistar testicular seminiferous tubule.
\end{abstract}

Keywords: Betel nut extract, Rattus norvegicus, testis, cyclooxygenase-2

\section{PENDAHULUAN}

Buah pinang merupakan bahan psikoaktif yang dikonsumsi ratusan juta orang di dunia khususnya di Asia Selatan (I). Di Taiwan, tercatat dua juta orang yang mengkonsumsi buah pinang sebagai suatu kebiasaan (2). Kebiasaan menyirih berhubungan erat dengan terjadinya fibrosis submucous oral, leukoplakia, dan kanker (3). Arecoline merupakan alkaloid utama dalam buah pinang yang banyak menyebabkan efek yang kurang menguntungkan seperti terjadinya mutagenitas, genotoksisitas dan sitotoksisitas pada berbagai sel mammalia $(4,5)$.

Pada mencit jantan, arecoline mampu merubah morfofungsi gonad, serta menginduksi bentuk abnormalitas sperma (6). Selain itu, arecoline juga mampu menghambat sintesis DNA pada sel germinal dan sel lainnya pada manusia $(6,7)$. Sebagai contoh arecoline (0.4-1.2 mM) dapat meningkatkan hiperpolarisasi potensial membrane mitokondria dan menginduksi fragmentasi DNA kecil pada sel kanker. Pemaparan arecoline pada sel-sel ovarium chinese hamster menyebabkan meningkatnya perubahan dan kelainan khromosomal (8). Pemaparan ekstrak biji pinang menginduksi terjadinya apoptosis pada sel spermatogenik, sel Sertoli dan sel Leydig tikus (9).

Jurnal Kedokteran Brawijaya, Vol. XXIII, No. 3, Desember 2007 Korespondensi: Aulanni'am, Laboratorium Biokimia, Jurusan Kimia Fakultas MIPA Universitas Brawijaya.

Telp :08123396700
Pemaparan dengan bahan-bahan aktif yang terkandung dalam buah pinang, utamanya arecoline akan menginduksi ekspresi enzim cyclooxygenase-2 (COX-2) yang sering dihubungkan dengan patogenesis fibrosis submucous oral dan kanker (10). Ekspresi COX-2 secara dominan ditemukan pada vas deferens dan sel epitel bagian distal cauda epididimis (11). Ekspresi COX-2 secara nyata ditemukan pada bagian distal vas deferens tikus (12). Namun sebaliknya hanya sedikit kadar COX-2 ditemukan pada testis manusia (13). Pada penelitian ini akan diuji pengaruh pemaparan ekstrak biji pinang (Areca catechu) terhadap ekspresi enzim COX-2 pada jaringan testis tikus.

\section{METODE}

Penelitian ini menggunakan hewan coba berupa tikus (Rattus norvegicus) galur Wistar sebayak 18 ekor dengan jenis kelamin jantan, berbadan sehat dengan berat badan 150 hingga 250 gram, usia 2 hingga 3 bulan yang dikelompokkan ke dalam 5 kelompok, yaitu PO (kontrol), tikus hanya diberi aquades, PI, PII, PIII, dan PIV, tikus dipapar dengan ekstrak biji pinang masing-masing dengan dosis 1, 2, 3, dan 4 gram/ekor selama 7 hari berturut-turut.

Biji pinang yang digunakan diperoleh langsung dari pohon pinang dari kebun pinang penduduk di Kelurahan Lhok Bengkuang, Kecamatan Tapaktuan, Kabupaten Aceh Selatan Nanggroe Aceh Darussalam. Pinang yang dipilih kulitnya yang sudah berwarna kuning, kondisi baik, tidak busuk dan tidak berjamur. 
Parameter yang diamati pada penelitian ini adalah ekspresi COX-2 pada jaringan tubulus seminiferus testis dengan metode Uji Imunohistokimia COX-2 (Santa Cruz Biotechnology Inc., CA.).

Pembuatan parafin block jaringan. Jaringan testis dicuci dengan PBS 3-5 x untuk membersihkan dari kontaminan. Kemudian difiksasi dengan formalin $10 \%$. Setelah itu dilakukan dehidrasi menggunakan alkohol bertingkat $(30 \%, 50 \%, 70 \%, 80 \%, 96 \%$ dan absolut) masing-masing 60 menit. Dilakukan clearing menggunakan xilol 2 kali masing-masing 60 menit. Kemudian dilakukan infiltrasi dengan parafin lunak selama 60 menit pada suhu $48^{\circ} \mathrm{C}$. Kemudian dilakukan block dalam parafin keras pada cetakan dan didiamkan selama sehari. Keesokan harinya ditempelkan pada holder dan dilakukan pemotongan setebal 4-6 $\mu \mathrm{m}$ dengan rotary microtome. Dilakukan mounting pada gelas objek dengan gelatin $5 \%$.

Proses deparafinisasi. Gelas obyek hasil parafin block direndam dalam xilol 2 kali masing-masing selama 5 menit. Setelah itu dilakukan rehidrasi menggunakan alkohol berseri (absolut, 96\%, 80\%, 70\%, 50\% dan 30\%) masingmasing selama 5 menit. Kemudian dibilas $\mathrm{dH} 2 \mathrm{O}$ selama 5 menit.

Metode pewarnaan imunohistokimia COX-2 SantaCruz. Slide dicuci dengan menggunakan PBS pH 7,4 satu kali selama 5 menit. Bloking endogenous peroksida menggunakan 3\% $\mathrm{H} 2 \mathrm{O} 2$ selama 20 menit. Cuci menggunakan PBS pH 7,4 tiga kali, masing-masing selama 5 menit. Bloking unspesifik protein menggunakan 5\% FBS yang mengandung $0,25 \%$ Triton $X-100$. Cuci menggunakan PBS pH 7,4 tiga kali masing-masing selama 5 menit. Inkubasi menggunakan antibodi primer, semalam pada suhu $40 \mathrm{C}$. Cuci menggunakan PBS pH 7,4 tiga kali, masing-masing selama 5 menit. Inkubasi menggunakan anti rabbit biotin conjugated selama satu jam pada suhu ruang. Cuci menggunakan PBS pH 7,4 tiga kali, masingmasing selama 5 menit. Inkubasi menggunakan SA-HRP (Strep-Avidin Horse Radis Peroxidase) selama 40 menit. Cuci menggunakan PBS pH 7,4 tiga kali, masing-masing selama 5 menit. Tetesi dengan DAB (Diamino Benzidine) dan inkubasi selama 10 menit. Cuci menggunakan PBS pH 7,4 tiga kali, masing-masing selama 5 menit. Counterstaining menggunakan Mayer Hematoxilen yang diinkubasi selama 10 menit dan cuci menggunakan tap water. Bilas menggunakan $\mathrm{dH} 2 \mathrm{O}$ dan dikeringanginkan. Mounting menggunakan entellan dan tutup dengan cover glass. Kemudian diamati di bawah mikroskop cahaya dengan pembesaran 1000x, ekspresi enzim COX-2 ditunjukkan dengan warna coklat pada jaringan tubulus seminiferus testis.
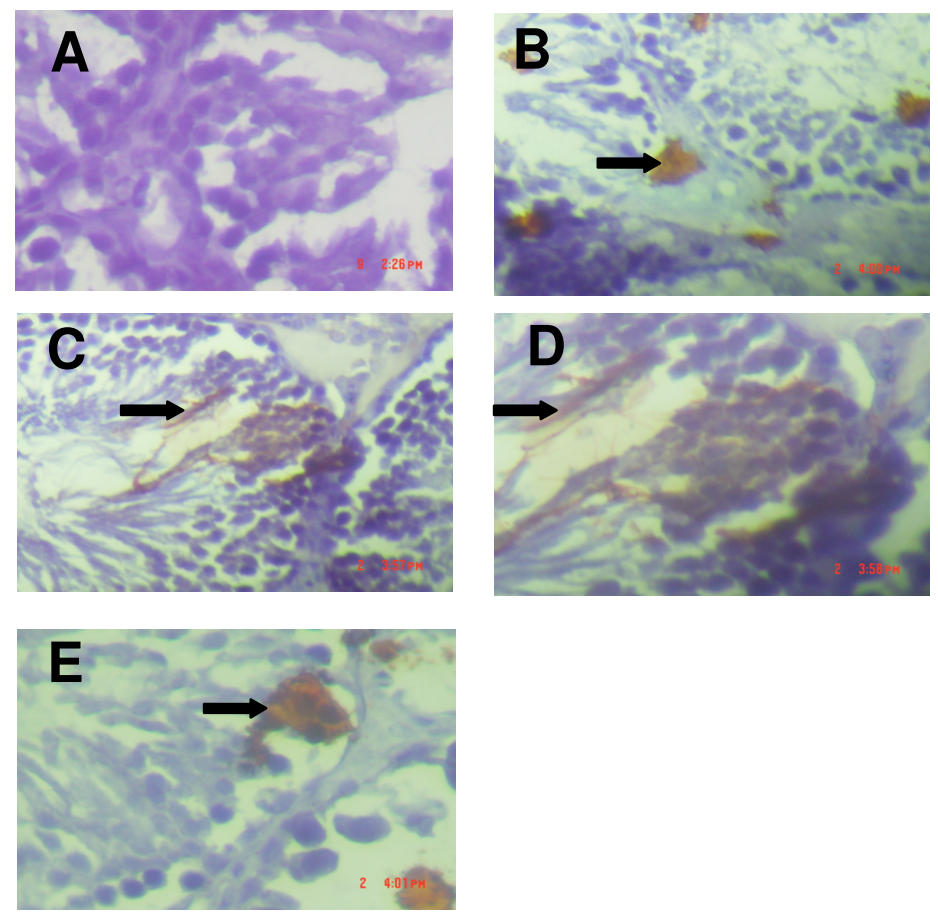

Gambar 1. Jaringan tubulus seminiferus testis kelompok PO yang dipulas dengan metode imunohistokimia COX2 (Santa Cruz Biotechnology Inc., CA). Tampak bahwa pada kelompok PO (panel A) tidak memperlihatkan adanya ekspresi COX-2. Hal ini sangat kontras dengan kelompok P1, P2, P2 dan P4 (Panel B, C, D dan E) yang diinduksi dengan ekstrak biji pinang dengan dosis 1, 2, 3, dan 4 gram/ekor selama 7 hari yang memperlihatkan adanya ekspresi COX-2 (warna coklat) pada jaringan tubulus seminiferus testis (tanda panah berwarna hitam). 


\section{HASIL PENELITIAN}

Pada penelitian ini, dengan induksi 1, 2, 3 dan 4 gram/ekor ekstrak biji pinang selama 7 hari berturut-turut, tampak terjadi ekspresi COX-2 pada jaringan tubulus seminiferus testis ditandai adanya warna coklat pada jaringan tubulus seminiferus testis yang merupakan visualisasi dari cromogen DAB (Diamino Benzidine). Akan tetapi, hal ini tidak terjadi pada kelompok kontrol yang hanya diberi aquades.

\section{DISKUSI}

Laporan tentang efek paparan biji pinang baik terhadap organ reproduksi manusia dan organ reproduksi hewan coba masih sangat jarang. Paparan terus menerus terhadap arecoline (bahan aktif utama biji pinang) dapat menginduksi produksi COX-2 yang mengindikasikan adanya keterlibatan pathway COX-2/PG (prostaglandin) terhadap sitotoksisitas oral dan tumorigenesis $(14,15)$. Mekanisme lain yang berperan dalam patogenesis oral adalah metalloproteinase-1 (16); sitokine (17) dan c-junprotooncogene (Ho et al., 2000). Ekspresi mPGES-1 berhubungan dengan COX-1 dan COX-2 dan melibatkan peran produksi PGE2 pada organ-organ genital jantan (11).

Belum ada bukti yang dapat menjelaskan korelasi antara paparan ekstrak biji pinang terhadap ekspresi COX-2 pada jaringan tubulus seminiferus testis. Namun telah diketahui bahwa paparan arecoline dapat menginduksi ekspresi COX-2 pada bagian distal vas deferens (12), epididimis, caput epididimis dan vas deferens pada semua stadium pematangan (18). Akan tetapi ekspresi COX-2 jarang ditemukan pada testis, epididimis, proksimal vas defe- rens atau prostate (12). Hasil penelitian oleh Kiong (19) menunjukkan adanya ekspresi COX-2 pada sel-sel sperma manusia yang diinduksi dengan arecoline.

Enzim siklooksigenase (cyclooxygenase $=\mathrm{COX}$ ) merupakan enzim kunci yang diperlukan untuk menghidrolisis asam arakidonat menjadi prostaglandin $(20,21)$. Ada 2 jenis enzim COX, yaitu: COX-1 dan COX-2. COX-1 terdapat hampir pada semua jaringan, terutama pada saluran pencernaan dan ginjal, yang mempertahankan fungsi fisiologi normal jaringan serta menginduksi fungsi platelet (19). Sedangkan COX-2 dianggap sebagai enzim pro-inflamasi (22). COX-2 dapat diinduksi oleh sejumlah faktor pertumbuhan dan sitokine (23). Ekspresi COX-2 merupakan suatu variasi respon fisiologis tubuh pada organisme, misalnya pada kondisi perlukaan jaringan dan inflamasi (24).

Hasil penelitian ini telah membuktikan bahwa paparan ekstrak biji pinang dalam berbagai variasi dosis dapat menginduksi ekspresi enzim COX-2 pada jaringan tubulus seminiferus. Hal ini disebabkan ekstrak biji pinang dengan bahan utamanya arecoline mampu melewati membrane basal tubulus seminiferus dan berinteraksi dengan komponen-komponen tubulus seminiferus. Ekspresi COX-2 terdistribusi disekitar sel-sel spermatogonia, spermatosit, spermatid, spermatozoa lumen tubulus seminiferus, dan jaringan interstitial.

\section{KESIMPULAN}

Parparan biji pinang dengan berbagai dosis akan menginduksi peningkatan ekspresi COX2 pada jaringan tubulus seminiferus testis tikus putih (Rattus norvegicus).

\section{DAFTAR KEPUSTAKAAN}

1. International Agency for Research on Cancer (IARC) 2004. Betel-quid and areca-nut chewing. http://www.inchem.org/documents/iarc/vol85/85-01-betel-areca.html [accesed 8 october 2007]

2. Ko YC, Chiang TA, Chang SJ, and Hsieh SF. Prevalence of betel quid chewing habbit in Taiwan and related sociodemografic factors. J. Oral. Pathol. Med, 1992; 24: 450-453.

3. Jacob BJ, K Straif, G Thomas, K Ramadas, B Mathew, ZF Zhang, R Sankaranarayanan and M Hashibe. Betel Quid Without Tobacco as a Risk factor per oral precancers. Ortal Oncol, 2004; 40: 697-704.

4. Chang MC, Ho YS, Lee PH, Chan CP, Lee JJ, Hahn LJ, Wang YJ and Jeng JH. Areca nut extract and arecoline induced the cell cycle arrest but not apoptosis of cultured oral KB cells: association of glutathione, reactive oxygen species and mitochondrial membrane potential. Carcinogenesis,2001; 22: 1527-1533.

5. Jeng JH, Chang MC, and Hahn LJ. Role of areca nut in betel quid-associated chemical carcinogenesis: Current awareness and future perspectives. Oral. Oncol. Pathol. Med,2001; 28: 64-71.

6. Sinha A. and Rao AR. Induction of Shape abnormality and unscheduled DNA syntesis by arecoline in the germ cells of mice. Mutat. Res, 1985; 158: 189-192.

7. Sharan WR and KK Wary. Study of unscheduled DNA synthesis following exposure of human cells to arecoline and extracts of betel nut in vitro. Mutat. Res., 1992; 278: 271-276.

8. Dave BJ, AH Trivedi, and SG Adhvaryu. In vitro genotoxic effect of Areca nut extract and arecoline. J. Cancer Res. Clin. Oncol., 1992; 118: 283-288. 
9. Akmal M, Aulanni'am, Rasmaidar, W Riawan, Masruri, M Adam, dan SI Maslikah. Pemanfaatan ekstrak biji pinang (Areca catechu) sebagai calon antifertilitas pria (studi berdasarkan distribusi apoptosis). Disampaikan Pada Seminar Nasional Obat Tradisional dan Tanaman Obat di Solo pada tanggal 10-11 Juli 2007.

10. Jeng JH, YS Ho, CP Chan, YJ Wang, LJ Hahn, D Lei, CC Hsu, and MC Chang. Areca nut extract up-regulate prostaglandin production, cyclooxygenase-2 mRNA and protein expression of human oral keratinocytes. Carcinogenesis, 2000; 21: 1365-1370.

11. Lazarus M, Munday CJ, Eguchi N, Matsumoto S, Killian GJ, Kubata BK, and Urade Y. Immunohistochemical localization of microsomal PGE synthase-1 and cyclooxygenases in male mouse reproductive organs. J. Endocrynology, 2002; 143: 2410-2419.

12. McKanna JA, Zhang M.Z, Wang JL, Cheng HF and Harris RC. Constitutive expression of cyclooxygenase-2 in rat vas deferens. Am J. Phyiol. 1998; 275: R227-R233.

13. O'Neill GP and Ford-Hutchinson AW. Expression of mRNA for cyclooxgenase-1 and cyclooxgenase-2 in human tissues. FEBS Lett.,1993; 330: 156-160.

14. Jeng JH, YJ Wang, BL Chiang, PH Lee, CP Chan, YS Ho, TM Wang, JJ Lee, LJ Hahn, and MC Chang. Role of keratinocyte inflammation in oral cancer: regulating the prostaglandin $E-2$, interleukin-6 and TNF-alpha production of oral epithelial cells by areca nut extract and arecoline. Carcinogenesis, 2003; 24: 1301-1315.

15. Tsai $\mathrm{CH}$, Chou MY and Chang YC. The up-regulation of cyclooxygenase-2 expression in human buccal mucosal fibroblasts by arecoline: a possible role in the pathogenesis of oral submucous fibrosis. Journal of Oral Pathology \& Medicine, 2003; 32 (3): 146-153.

16. Shieh DH, LC Chiang, and TY Shieh. Augmented mRNA exspression of tissue inhibitor of metalloproteinase-1 in buccal mucosal fibroblast by arecoline and safrole as a possible pathogenesis for oral submucous fibrosis. Oral. Oncol, 2003; 39: 728-735.

17. Hsu HJ, KL Chang, YH Yang and TY Shieh. The effects of arecoline on the release of cytokines using cultured peripheral blood mononuclear cells from patients with oral mucous diseses. Kaohsiung J. Med. Sci., 2001; 17: 175-182.

18. Stanfield KM and KN Khan. Localization of COX-2 in the male reproductive tract during sexual maturation. Inflammopharmacology, 2003; 11: 259-266.

19. Kiong Er, Eing-Mei Tsai, Li-Yu Tsai, Ying-Chin Ko and Jau-Nan Lee. In vitro effects of arecoline on sperm motility and cyclooxygenase-2 expression. J. Toxicological sciences. 2006; 31: 75-82.

20. Dubois R.N. Cyclooxygenase in biology and disease. FASEB. J., 1998; 12:1063-1073.

21. Vane JR and RM Botting. The mechanism of action of aspirin. Thrombosis Res. 2003; 110:255-258.

22. Derek WG. Inducible cyclooxygenase may have anti-inflammatory properties. Nat. Med. 1999; 5(6):698-701.

23. Warner TD and JA Mitchell. Cyclooxygenase: New forms, new inhibitors, and lessons from the clinic. FASEB J., 2004;18: 790-804

24. Tippetts MT, BC Varnum, RW Lim, and HR Herschman. Tumor promoter-inducible genes are differentially expressed in the developing mouse. Mol Cell Biol., 1998; 8: 4570-4572. 